\title{
CHARACTERIZATION OF DSSCS USING NATURAL COLORANTS AS SENSITIZERS
}

\author{
M. Devi ${ }^{1}$, R. K. Saini ${ }^{2}, \bowtie$ and S. Shrivastava ${ }^{1}$ \\ ${ }^{1}$ Department of Chemistry, Kalinga University, Naya Raipur- 492101 (Chhattisgarh), India \\ ${ }^{2}$ Department of Chemistry, Goswami Ganesh Dutt Sanatan Dharma College, Palwal-121102 \\ (Haryana), India \\ ${ }^{\otimes}$ Corresponding Author: ramansaini07@gmail.com
}

\begin{abstract}
The natural colorants extracted from flowers of Chrysanthemums and Dianthus barbatus were used as sensitizers in the making of dye-sensitized solar cells (DSSCs). The FTO-coated transparent substrate was used. The nanoparticles of $\mathrm{TiO}_{2}(\mathrm{P} 25)$ were applied as a semiconductor for photoanode. The Chrysanthemums flower extracted colorant UVVis spectrum showed extensive absorption peaks at $411,428 \mathrm{~nm}$, and $663 \mathrm{~nm}$ in the visible region. The absorption peak was observed at $336 \mathrm{~nm}$ in the spectrum for the Dianthus barbatus flowers extracted colorant. The optical band gap was calculated using Tauc's relation i.e. 2.66 and $3.10 \mathrm{eV}$ for Chrysanthemums and Dianthus barbatus flowers colorant, respectively. The photovoltaic properties were studied with redox electrolyte $\mathrm{NaI}$ and $\mathrm{KI}$ with $\mathrm{I}_{2}$ in acetonitrile solvent. The fabricated solar cells show good photovoltaic properties. The dyes have good prospects as a low-cost and environmentally friendly alternative to costly synthetic dyes and metal complexes-based sensitizers which are frequently used in DSSCs.
\end{abstract}

Keywords: DSSCs, Natural Dyes, Optical Band Gap, Redox Electrolytes.

RASĀYAN J. Chem., Vol. 14, No.2, 2021

\section{INTRODUCTION}

The energy crisis increasing day by day, so it is necessary to develop sustainable energy sources. The main challenge to develop sustainable energy sources are to produce an eco-friendly, economical and reliable product. Solar photovoltaics have great attention over the last decades due to their reliability and eco-friendly nature. Dye-sensitized solar cells (DSSC) have the potential to substitute the silicon-based photovoltaic cells. In 1991, O'Regan and Gratzel first introduces the DSSC 7.1-7.9\% efficiency under illumination by Sun simulated AM 1.5 solar light ${ }^{1}$. The DSSC has five components i.e. substrate, photoanode, sensitizer, a counter electrode, and electrolyte. The sensitizer has a significant role for improve performance by increasing light absorption and decrease of the cost. Various metal complexes and synthetic dyes i.e. Ru, Os, Ir, etc. shows good properties as a sensitizer, however, these have a high cost. The alternate of these costly synthetic sensitizers is natural dyes extracted from several parts of plants. The efficiency of natural dyes-based solar cells is lower as compared to synthetic dye-based DSSC, still, these are effective due to lower cost. The natural dyes have carotene, tannin, chlorophyll, aurone, anthocyanins, etc. like components responsible for color as well as absorption of solar radiations. The advantages are low-cost extraction, low toxicity, high light-harvesting efficiency, and higher absorption coefficients, So, the fabrication of DSSCs less challenging. ${ }^{2-4}$

Several natural dyes as sensitizer have been reported for photovoltaic properties in DSSCs, these shows around $1 \%$ conversion efficiency. ${ }^{2,5-6}$ Chrysanthemums (also known as chrysanths, or mums) belong to the Asteraceae family and Chrysanthemum genus. It is herbaceous sub-shrubs or perennial plants flowering plant. These are cultivated in Asia, Europe, China as ornamental plants in the garden. Chrysanthemum petals can be used as a dye for coloring silk and cotton fabrics. Chrysanthemum flowers contained the anthocyanins like cyanidin 3-(3"-malonoyl) glucoside and cyanidin 3-glucoside. ${ }^{7}$ These flowers also have carotenoids i.e. trans- $\beta$-carotene, 9 -cis- $\beta$-carotene, $\alpha$-carotene, 13 -cis- $\beta$-carotene, $\beta$ cryptoxanthin, zeaxanthin, and lutein. ${ }^{7}$

Dianthus barbatus (also known as Sweet William) belong to the Caryophyllaceae family and Dianthus genus. It is a seasonal biennial or a perennial decorative plant. These plants have medicinal values like 
RASĀYAN J. Chem.

Vol. 14 | No. 2 |1110-1115| April - June | 2021

anti-insecticide activities, ${ }^{8}$ antifungal, ${ }^{9-10}$ antibacterial, ${ }^{11}$ antiviral, ${ }^{12-13}$ and anticancer. ${ }^{14}$ A phenolic compound present in plant extraction, i.e. Kaempferidetri glycoside exhibits anti-cancer properties. The extraction of dark red color flowers, essential oil exhibits larvicidal activity and arthropods repellent. The red and pink color in the flower of Dianthus was mainly due to anthocyanins i.e. pelargonidin 3malylglucoside and cyanidin 3-malylglucoside. ${ }^{15}$ In this present work, the optical and photovoltaic performance of fabricated DSSCs had been studied using natural colorant extracted from flowers of Chrysanthemums and Dianthus barbatus as a sensitizer. The photoelectrochemical properties of prepared DSSCs have been represented using redox electrolytes i.e. sodium iodide (NaI), potassium iodide (KI) with iodine $\left(\mathrm{I}_{2}\right)$ as in acetonitrile (AN) solvent.

\section{Chemicals and Instruments}

EXPERIMENTAL

FTO (Fluorine doped tin oxide) coated transparent conducting glass substrate having resistance 6-8 $\Omega / \mathrm{cm}^{2}$ purchased from Sigma-Aldrich was used in the fabrication of DSSCs. The redox electrolytes were used i.e. sodium iodide $(\mathrm{NaI})$, potassium iodide $(\mathrm{KI})$ with iodine $\left(\mathrm{I}_{2}\right)$ in acetonitrile solvent. $\mathrm{Nano}-\mathrm{TiO}_{2}$ conventionally available titania P25 was used for making photoelectrode. The UV-Vis spectrophotometer (Shimadzu 2450) having a range $180-1100 \mathrm{~nm}$ was used to obtain UV-Vis absorption spectra in a proper solvent. The solar cells were stimulated with light irradiation produced by a tungsten (W) arc lamp of 200W. The digital source meter of Keithley model 2450 with kickstart software controlled by a computer was used to obtain the I-V graph.

\section{Fabrication of DSSCs}

The adequate size of the transparent conducting substrate was taken for the fabrication of DSSCs. The substrate was clean with the neural soap solution and sonicated in soap solution for $15 \mathrm{~min}$. The substrate was rinsed with distilled water to remove the soap. The substrate was sonicated with hot water for 10 min. The conducting substrate was boiled with acetone solvent. Finally, the substrates were boiled in propan-2ol solvent for removal of organic solvent. The cleaned substrates were dried in an oven at $80{ }^{\circ} \mathrm{C}$. The counter electrode was prepared by applied layer carbon (graphite) on the flame. The masking of the substrate was done with adhesive plastic tape. The desire portion was left unmasked for deposition of the $\mathrm{TiO}_{2}$ layer. A small portion of titania P25 (nano-titanium dioxide particles) was added within the small portion of glacial acetic acid mixed it properly to make it lump-free. If more amount of glacial acetic acid need it added in small portion $0.1 \mathrm{ml}$ to form a proper paste. The paste was transfer toa small vial and sonicated in hot water for 30 minutes. The $\mathrm{TiO}_{2}$ paste was applied on an unmasked portion of the substrate and spread by the doctor blade technique. After removal of plastic tape, the prepared $\mathrm{TiO}_{2}$ film was sintered for $2 \mathrm{~h}$ at $300^{\circ} \mathrm{C}$.

\section{Preparation of Dyes and Electrolyte Solutions}

The Chrysanthemums flowers were washed with distilled water and crushed in pestle and mortar. The mixture was put in a conical flask with ethanol solvent. The mixture was kept in a conical flask for maximum extraction for 24 hours at room temperature. Then, the mixture was filtered with Whatman filter paper. The colorants were extracted by preparing ethanol solvent of the Dianthus barbatus flower. The extraction process was carried out on a water bath for 6 hours at $70^{\circ} \mathrm{C}$ of temperature. Coloring materials from the flowers were extracted and filtered through filter paper. The redox electrolytes were formed by mixing sodium iodide $(\mathrm{NaI})(0.1 \mathrm{M})$ or potassium iodide $(\mathrm{KI})(0.1 \mathrm{M})$ with iodine $\left(\mathrm{I}_{2}\right)(0.01 \mathrm{M})$ in acetonitrile solvent. The extracted colorant exhibits good absorption on $\mathrm{TiO}_{2}$ film as represented in Fig.-1.

\section{UV-Vis Spectrum of Natural Colorants extracted from Flowers}

The UV-Vis spectrum of Chrysanthemums and Dianthus barbatus flowers extract in ethanol solvent was taken and represented in Fig.-2. UV-Vis absorption spectrum analysis help in the identification of refractive index extinction coefficient, bandgap, impurity states, etc. The optical absorption studies play a vital task in giving an insight into transition, the nature of bandgap either direct or indirect. The UV-Vis spectrum was used to calculate the energy band gaps and the optical properties of the natural dyes. 
RASĀYAN J. Chem.

Vol. 14 | No. 2 |1110-1115| April - June | 2021

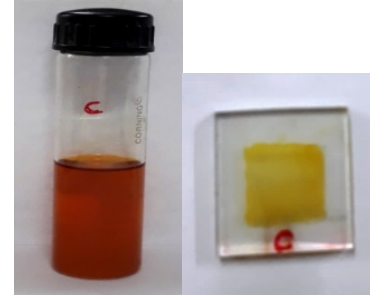

(A) Chrysanthemum

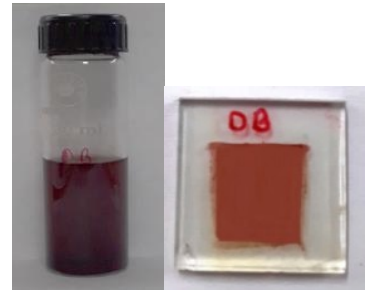

(B) Dianthus Barbatus

Fig.-1:Natural extracted colorant with the absorption of dye on $\mathrm{TiO}_{2}$ film (A) Chrysanthemum and (B) Dianthus Barbatus

The relationship among absorption coefficient, optical band gap $\left(\mathrm{E}_{\mathrm{g}}\right)$, and energy $(\mathrm{h} v)$ of the incident photon is given by eqn.- 1 .

$$
\alpha h v=A\left(h v-E_{g}\right)^{r}
$$

Where, $E_{\mathrm{g}}$ is optical energy gap, $\mathrm{A}$ is constant, $\mathrm{h}$ is the Planck's constant $\left(6.625 \times 10^{-34} \mathrm{~J} / \mathrm{s}\right)$

$$
\alpha=\left(h v-E_{\mathrm{g}}\right)^{1 / 2} / \mathrm{h} v
$$

The optical band gap $\left(E_{g}\right)$ of natural colorant was obtained by plotting $(\alpha h v)^{2}$ Vs energy in $\mathrm{eV}^{16-18}$ The Chrysanthemums flower extraction exhibits extensive absorption peaks at 411 and $428 \mathrm{~nm}$ in the visible region. UV-Vis absorption spectrum also shows an absorption peak at $663 \mathrm{~nm}$. The absorption spectra of dyes show the possibility of electron transition among excited state and ground state. The optical bandgap of the extract was obtained $2.66 \mathrm{eV}$ calculated by using Tauc's equation and shown in Fig.-3. The absorption peak was observed at $336 \mathrm{~nm}$ in the spectrum for the Dianthus barbatus flowers extracted colorant. The optical band of colorant was found $3.10 \mathrm{eV}$. The absorption of radiation in the visible region shows it can be used in the formation of DSSCs as a sensitizer.

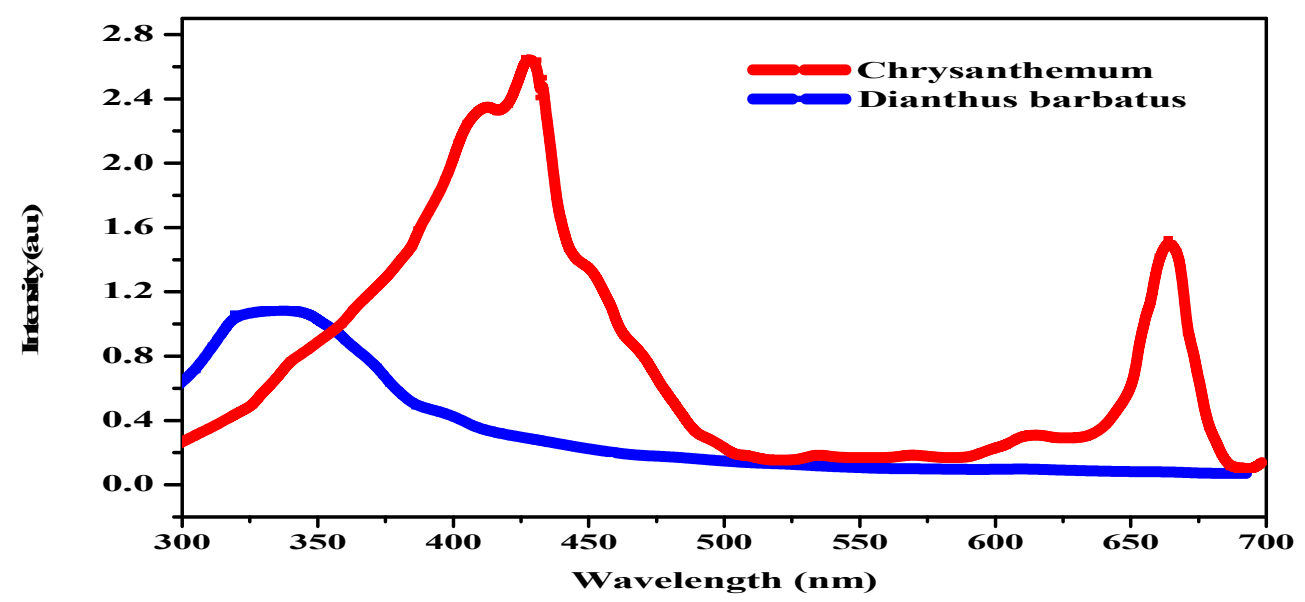

Fig.-2: UV-Vis Spectrum of Natural Colorants extracted from Flowers of Chrysanthemum and Dianthus Barbatus

\section{Photovoltaic Properties of Fabricated DSSCs}

The DSSCs were fabricated FTO coated glass-based substrate, commerciallyavailable nano-titania (nanoparticles $\mathrm{TiO}_{2}$ i.e. P25), Chrysanthemums, and Dianthus barbatus flowers extract colorant as a sensitizer. The redox electrolytes were used $\mathrm{NaI}$ and $\mathrm{KI}$ with $\mathrm{I}_{2}$ in acetonitrile solvent. The photovoltaic properties were studied with the current density-potential $(\mathrm{J}-\mathrm{V})$ curve of fabricated DSSCs under the illumination of $200 \mathrm{~W}$ tungsten arc. The J-V curve is represented in Fig.-4. The following parameter was open-circuit voltage $\left(\mathrm{V}_{\mathrm{oc}}\right)$, short-circuit current $\left(\mathrm{J}_{\mathrm{sc}}\right)$, fill factor $(F F)$ and efficiency $(\mathrm{n})$ were obtained by $\mathrm{J}-\mathrm{V}$ curve. The detailed photovoltaic parameters of fabricated DSSCs are shown in Table- 1 . The relation among the fill factor $(F F)$ and power conversion efficiency $(\eta)$ were calculated by the following: ${ }^{19-22}$ 
RASĀYAN J. Chem.

Vol. 14 | No. 2 |1110-1115| April - June | 2021

$$
\begin{aligned}
& F F=\frac{J_{\text {max }} \cdot V_{\text {max }}}{J_{\text {sc }} \cdot V_{\text {oc }}}=\frac{P_{\max }}{J_{\text {sc }} \cdot V_{\text {oc }}} \\
& \eta=\frac{J_{\text {sc. }} V_{\text {oc }} \cdot F F}{P_{\text {in }}} \times 100
\end{aligned}
$$

The fabricated devices studied were with the following configuration:

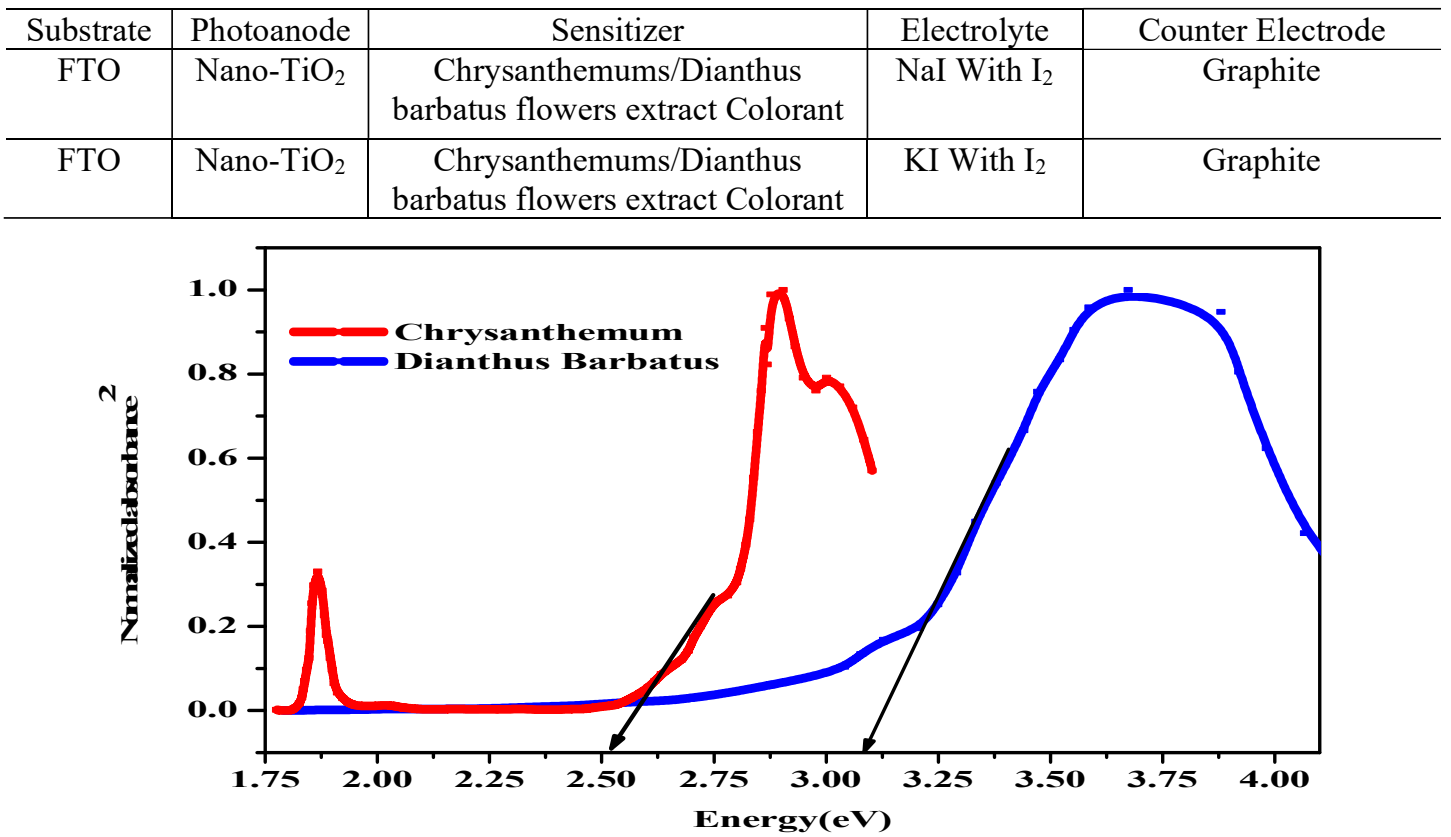

Fig.-3: Optical Band Gap of Natural Colorants extracted from Flowers of Chrysanthemum andDianthus Barbatus

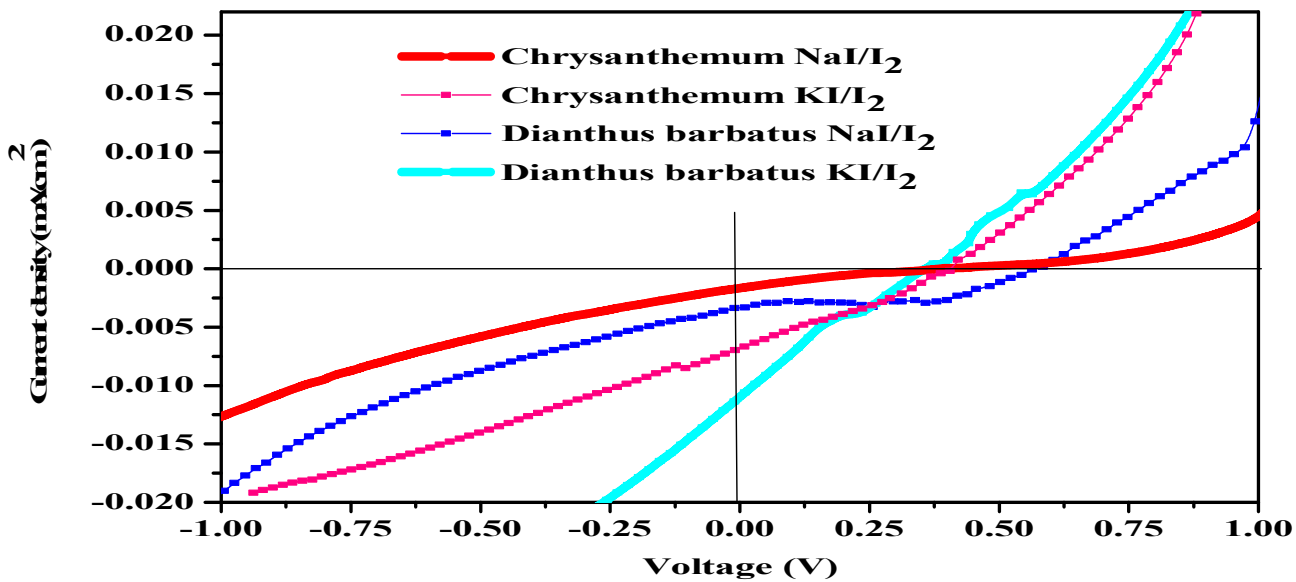

Fig.-4: Current-voltage Plot of fabricated DSSCs with $\mathrm{NaI} / \mathrm{I}_{2}$ and $\mathrm{KI} / \mathrm{I}_{2}$ Electrolytes using Natural Colorants as Sensitizers

The redox electrolyte NaI- $\mathrm{I}_{2}$ in acetonitrile with Chrysanthemums flowersextracted colorant was found $\mathrm{J}_{\mathrm{sc}}$ of $1.72 \mathrm{~mA} / \mathrm{cm}^{2}$ and $\mathrm{V}_{\text {oc }}$ of $0.354 \mathrm{~V}$. In another redox electrolyte $\mathrm{KI}-\mathrm{I}_{2}$ in acetonitrile shown the $\mathrm{V}_{\text {oc }}$ of $0.405 \mathrm{~V}$ and $\mathrm{J}_{\mathrm{sc}}$ of $6.97 \mathrm{~mA} / \mathrm{cm}^{2}$. The DSSCs were shown the Fill factor (FF) 0.178 and 0.272 with redox electrolyte NaI- $\mathrm{I}_{2}$ and $\mathrm{KI}-\mathrm{I}_{2}$ respectively. The efficiency of fabricated solar cells was found $0.115\left(\mathrm{NaI}-\mathrm{I}_{2}\right)$ and $0.768\left(\mathrm{KI}-\mathrm{I}_{2}\right)$.

The short circuit current density $\left(\mathrm{J}_{\mathrm{sc}}\right)$ of DSSC with redox electrolyte $\mathrm{NaI}-\mathrm{I}_{2}$ was found 3.37 while in redox electrolyte $\mathrm{KI}-\mathrm{I}_{2}$ was found $11.30 \mathrm{in} \mathrm{mA} / \mathrm{cm}^{2}$ in Dianthus barbatus flower extract.The open-circuit voltage $\left(\mathrm{V}_{\mathrm{oc}}\right)$ was obtained in redox electrolyte $\mathrm{NaI}-\mathrm{I}_{2} 0.563 \mathrm{~V}$ and redox electrolyte $\mathrm{KI}-\mathrm{I}_{2} 0.358 \mathrm{~V}$. The 
RASĀYAN J. Chem.

Vol. 14 | No. 2 |1110-1115| April - June | 2021

fill factor (FF) of the photovoltaic device was found $0.392\left(\mathrm{NaI}-\mathrm{I}_{2}\right)$ and $0.216\left(\mathrm{KI}-\mathrm{I}_{2}\right)$. The higher efficiency $(\eta)$ of the cell was obtained with $\mathrm{KI}-\mathrm{I}_{2}$ redox electrolyte where the lower efficiency was with NaI-I $\mathrm{I}_{2}$ electrolyte.

Table-1: Photovoltaic properties of Natural colorants as a sensitizer

\begin{tabular}{c|c|c|c|c|c}
\hline \multicolumn{6}{c}{ Chrysanthemums Flower Colorant as a Sensitizer } \\
\hline 1 & $\mathrm{NaI}_{2}$ & 0.354 & 1.72 & 0.178 & 0.11 \\
\hline 2 & $\mathrm{KI}_{2}$ & 0.405 & 6.97 & 0.272 & 0.768 \\
\hline \multicolumn{6}{c}{ Dianthus barbatus Flower Colorantas a Sensitizer } \\
\hline S.No. & Electrolytes & $\mathrm{V}_{\text {oc }}(\mathrm{V})$ & $\mathrm{J}_{\text {sc }}\left(\mathrm{mA} / \mathrm{cm}^{2}\right)$ & Fill factor $(\mathrm{FF})$ & Efficiency \\
\hline 3 & $\mathrm{NaI}_{2}$ & 0.563 & 3.37 & 0.392 & 0.745 \\
\hline 4 & $\mathrm{KI}_{2} \mathrm{I}_{2}$ & 0.358 & 11.30 & 0.216 & 0.883 \\
\hline
\end{tabular}

\section{CONCLUSION}

DSSCs were made using Chrysanthemumsand and Dianthus barbatus flowers extract colorant as sensitizer with redox electrolytes i.e. $\mathrm{NaI}$ and $\mathrm{KI}$ with $\mathrm{I}_{2}$ in acetonitrile solvent. The nano-particles of $\mathrm{TiO}_{2}$ were used as photoanode for making of DSSCs. The absorption spectra exhibited naturally extracted colorants could be applied as a sensitizer in DSSCs. The optical band gap was found good i.e. 2.66 and $3.10 \mathrm{eV}$ for Chrysanthemums and Dianthus barbatus flowers extract colorant, respectively. The current density short circuit was found in range 1.78 to $11.3 \mathrm{~mA} / \mathrm{cm}^{2}$ while $\mathrm{V}_{\text {oc }}$ was found in range 0.354 to 0.564 $\mathrm{V}$. The maximum efficiency was found in Dianthus barbatus flowers colorant with $\mathrm{KI} / \mathrm{I}_{2}$ redox electrolyte. The efficiency of the DSSCs can be improved by changing the redox electrolytes.

\section{ACKNOWLEDGEMENT}

The authors are gratefully thankful to Head, Department of Chemistry, Kalinga University, Naya Raipur492101 (Chhattisgarh), India, for providing necessary facility for carrying out research work

\section{REFERENCES}

1. B. O'regan, M. Grätzel, Nature, 353(6346), 737(1991), DOI:10.1038/353737a0

2. H. Hug, M. Bader, P. Mair, T. Glatzel, Applied Energy, 115, 216(2014), DOI: 10.1016/j.apenergy.2013.10.055

3. R. K. Saini, D. Singh, S. Bhagwan, Emerging Photovoltaic Materials, 12, 443(2019).

4. G. Calogero, J.H. Yum, A. Sinopoli, G. Di Marco, M.Grätzel, M. K. Nazeeruddin, Solar Energy, 86(5), 1563(2012), DOI:10.1016/j.solener.2012.02.018

5. M. Shahid, F. Mohammad, Journal of Cleaner Production, 53, 310(2013), DOI: $10.1016 / j$ j.jclepro.2013.03.031

6. N.A. Ludin, A.A.A. Mahmoud, A.B. Mohamad, A.A. Kadhum, K.Sopian, N. S. A.Karim, Renewable and Sustainable Energy Reviews, 31, 386(2014), DOI:10.1016/j.rser.2013.12.001

7. C. H. Park, S. C.Chae, S. Y.Park, J. K.Kim, Y. J.Kim, S. O.Chung, S.U.Park, Molecules, 20(6), 11090 (2015), DOI:10.3390/molecules200611090

8. A. C. Kimbaris, G. Koliopoulos, A. Michaelakis, M.A. Konstantopoulou, Parasitology Research, 111(6), 2403(2012), DOI:10.1007/s00436-012-3097-1

9. P. Curir, M. Dolci, V. Lanzotti, O. Taglialatela-Scafati, 56(7), 717(2001), DOI:10.1016/s00319422(00)00488-X

10. F. Galeotti, E. Barile, P. Curir, M. Dolci, V. Lanzotti, Phytochemistry Letters, 1(1), 44(2008), DOI: $10.1016 /$ j.phytol.2007.10.001

11. I. Castillo-Juárez, V. González, H. Jaime-Aguilar, G. Martínez, E. Linares, R. Bye, I. Romero, Journal of Ethnopharmacology, 122(2), 402(2009), DOI:10.1016/j.jep.2008.12.021

12. E. DeClercq, Medicinal Research Reviews, 20(5), 323(2000), DOI:10.1002/10981128(200009)20:5<323::AID-MED1>3.0.CO;2-A

13. S. H. Desai, K. Majumdar, K. S. Kulkarni, Journal of Herbal Medicine and Toxicology, 3(1), 117(2009).

14. V. Martineti, I. Tognarini, C. Azzari, S. C.Sala, F.Clematis, M.Dolci, P.Curir, Phytotherapy Research, 24(9), 1302(2010), DOI:10.1002/ptr.3105 
RASĀYAN J. Chem.

Vol. 14 | No. 2 |1110-1115| April - June | 2021

15. N.Terahara,M. A.Yamaguchi, K.Takeda, J. B.Harborne, R.Self, Phytochemistry, 25(7), 1715(1986), DOI: 10.1016/S0031-9422(00)81242-X

16. J. Tauc, The Optical Properties of Solids, F. Abeles (Ed.), North-Holland, Amsterdam, 37(1972),

17. M. M.El-Nahass, A. M.Farag, K. F.Abd El-Rahman, A. A. A.Darwish, Optics \& Laser Technology, 37(7), 513(2005), DOI: 10.1016/j.optlastec.2004.08.016

18. F. Yakuphanoglu, M. Arslan, Optical Materials, 27(1), 29(2004), DOI:10.1016/j.optmat.2004.01.017

19. R. K. Saini, D. Singh, S. Bhagwan, V. Nishal, Sonika, I. Singh, P. S. Kadyan, Journal of Nanoelectronics and Optoelectronics, 11(5), 715(2016), DOI:10.1166/jno.2016.1944

20. R. K. Saini, D. Singh, S. Bhagwan, Sonika, I. Singh, P. S. Kadyan, Der Pharma Chemica, 7(8), 162(2015).

21. Z. Lan, J. Wu, D. Wang, S. Hao, J. Lin, Y. Huang, Solar Energy, 81(1), 117(2007), DOI: 10.1016/j.solener.2006.05.003

22. Y. Liu, A. Hagfeldt, X. R.Xiao, S. E.Lindquist, Solar Energy Materials and Solar Cells, 55(3), 267(1998), DOI:10.1016/S0927-0248(98)00111-1

[RJC-6169/2020] 